\title{
PROBLEMS OF RENDERING IT TERMINOLOGY \\ INTO ARABIC
}

By

Ramy Hamza Mohamed Shenishen

Prof.mohamed Said Negm

Professor of linguistics,Faculty of Arts_Tanta Unversity

Dr.Gamal Hegazy

Lecturer of English Literature,Faculty of Arts_Tanta Unversity

\section{Abstract:}

This paper investigates translation problems and obstacles in the translation of IT texts from English into Arabic. It explores the numerous challenges and issues that professional $I T$ translators face in dealing with localizing IT projects. Considering that localization is an activity constrained by limitations of time, process, and cost, IT translators need to make use of their entire skillset to overcome the varied challenges imposed by the source text and the localization process itself. The present paper provides a ranked classification of problems in translating from English into Arabic through browsing some unique and important web applications such as Oracle, Microsoft, Google, and SAP systems. 
The paper concentrates on the causes that lead to such issues and problems and provides the possible and available solutions to avoid such problems. This paper aims to analyze and identify the functional approaches in translating technical IT terms, focusing on the main issues that face IT technical translators.

The current paper follows Skopos methodology, which takes into account the cultural and environmental standards when transferring the translated text from English into Arabic, thus the technical translator must be highly conversant and have extensive experience with the culture and environment in which the translated text will be marketed. It also cares about the constraints and obstacles of the Arabic language systems and dimensions and how to avoid them in combining English terms within Arabic translated text. Finally, the paper focuses on the identification and categorization of problems of localization of online help files for web applications. Online help is a digital product that offers assistance to the user to carry out tasks in a specific application or that answers questions about specific aspects of the interface of the application, its operation, or its characteristics. The central question of this paper covers broadly the kinds of problems that a translator faces in the localization process of online help.

Keywords: Arabic translation - information technology - localization online help - acceptability- equivalence- Skopos theory. 


\section{Introduction}

Communication is an activity that has always been important in contact between communities and individuals. It is a medium of communication through languages and cultures. It is considered a modern science on the borderline of philosophy, linguistics, psychology, and sociology (Enani, 1997, p. 5). The term "translation" refers to an academic discipline; the process of translation between two languages (Munday 2001 , p. 405). Such definitions highlight the importance of rendering a text in one language into an equivalent text in another language. The translator has two roles when reading a text; he is, first of all, attentive to the details and then he becomes the author of the translated text. To be able to translate, he must understand the text and master certain basic knowledge, that is to say, linguistic and extra-linguistic. The linguistic knowledge of the translator is part of his cognitive background and is essential for an understanding of texts and his re-expression. Yet, "Linguistics alone will not help us. Translation is not merely, and not even primarily a linguistic process" (Nord, 2001, p. 10). It is a process, a product, and even a function as Gideon Toury states (1995, p. 29). However, this is not enough to manage to grasp the meaning of a text. Extra-linguistic knowledge is a part of comprehension.

Translation is a creative as well as an interesting job. Good writing and translation skills make the content of the translated text rich and valuable. Rich and powerful language enables the translator to have his messages moved between source and target languages. This concept, as per Vinay \& Darbelnet's translation procedures, helps the translator to look through IT terms outside the context and decide whether the 
localized IT segments are morphemes, words, or phrases. As per Vinay \& Darbelnet's concept of translation, there are six procedures of translating terms: direct borrowing, calque or loan translation, literal translation, transportation, modulation, and adaptation.

Technical IT language is expressed precisely by definite and limited lexical terms. Likewise, semi-technical terms can be used necessarily in the case of using derived and multi-usage terms. Meanwhile, standardization in translating Arabic IT terms is so essential for professional localized output. It seems necessary to bring to the attention of the reader the form used to present this work, at the meeting of two disciplines, translatology and computer linguistics. The first is more anchored in literary studies, even its developments in pragmatic translatology directly concern translation practices and the training of translators; it is based on old or at least classical references and is expressed in a sustained language. The second form, on the contrary, rests on a more concise language, because it comes from the word of exact sciences. To write this paper, the researcher, therefore, had to find an equivalent that meets both the paper adopted in translating theses and the criteria of specialists in the development of computer tools. This research is driven by the following objectives:

- To test the effects of the differences between English and Arabic on the adequacy of the translation through Skopos theory.

- To investigate the approach that the translators followed to overcome the problems of translating IT terminology. 
- To examine how far translators' competence could solve the problems of translating IT terminology.

\section{Theoretical Perspective}

Epistemologically speaking, technical translation into Arabic is a daunting task that requires both linguistic competence and technical background, especially in light of the vast speed of technology. This ever-expanding wave poses serious problems to Arabic with the shortage of equivalent terminology that covers the technological field due to the differences between Arabic and English. Whenever there is a lack of an equivalent term, different translation strategies take place to delimit the foreignness of translated terminology. Yet, with the high demand for technical translation and the customer's interest, the need for an increase in the studies of translation tools has become an ultimatum. Regarding this, Newmark (1991) notes: "In science, the language is concept-centered; in technology, it is object-centered" ( $p$. 155) While Ghazala defines technical translation as, "the translation of scientific and technical terms of all kinds: medical, physical, chemical, mathematical, mechanical, technological, biological, agricultural, computer and other terms of the various branches of science" (p. 156), Wright \& Wright's definition includes the translation of special language texts, i.e., texts written using Languages for Special Purposes (p. 1).

This paper is descriptive, comparative, and analytical in nature. It attempts to present a descriptive and an analytical study of the linguistic aspects surrounding the Arabic term translated from English, starting from clarifying the importance of the term industry and the need to build 
a terminology bank in all fields, as well as addressing the problems faced by the translator during the translation process in building a term. The paper will also discuss the derivatives of Arabic pronunciation, their uses, and the benefits to the translation industry in the modern era. Also, the researcher will discuss the reasons leading to mixing English words in an Arabic term and their integration to become one of the daily words used by the majority of Arabs. The paper will also deal with the characteristics of the term, its composition, and components, the conditions for the development of the Arabic term and, the means of building terminology in the modern era.

In light of Skopos theory discussed by Jeremy Munday (2016) and was introduced in the 1970 s by Hans J. Vermeer, there is not enough attention to the linguistic nature of the source text, because linguistics alone is not a great help. This theory is a framework for a general theory of translation as claimed by Nord (2012, p.27). Here, a shift is made linguistically oriented concepts to a functionally oriented framework. Because the Greek meaning of the word "Skopos" is a purpose, IT translation should be purpose-oriented where the ST is information that needs to be modulated according to the target culture. Skopos theory allows translators to be creative and practical where the final product will meet the purpose intended.

\section{Vermeer's skopos theory}

Skopos theory is a theory of translation by the German translator Vermeer in 1978. In this theory, the process of translation is determined by the function of the product. This function is specified by the addressee. This theory is one of the functionalist approaches whose aim 
is to dethrone the source text (ST). This is done by emphasizing the role of the translator as a creator of the target text (TT)and giving priority to purpose(skopos)of producing TT. Functionalism is a major shift from a linguistic equivalence to functional appropriateness. Thus, translation is considered primarily as a process of intercultural communication whose end product is a text which has the ability to function appropriately in specific situations and context of use(Schaffner,1998:3).

Skopos is a Greek word for 'purpose'. According to Skopostheorie, the basic principle which determines the process of translation is the purpose (skopos) of the translational action. The idea of intentionality is part of the very definition of any action (Nord,1997:27).

Translation is viewed not as a process of trans-coding, but as a specific form of human action. Like any other human action, translation has a purpose, and the word skopos, derived from Greek, is used as the technical term for the purpose of a translation. Skopos must be defined before translation can begin; in highlighting skopos, the theory adopts a prospective attitude to translation, as opposed to the retrospective attitude adopted in theories which focus on prescriptions derived from the source text. In addition to its purpose, any action has an outcome.

\section{Material Studied}

The data of the current work have been collected from open access software websites. The data used are related to the websites of some of the largest international companies working in the field of information technology. Among these companies, we can find Microsoft, SAP, and Oracle. As for the applications used during this paper, the researcher relied on SDL Trados Studio and MemoQ applications. Some references 
and printed books specialized in the field of terminology and translation have been consulted too. The researcher had already used several translated texts in actual online sessions. The translated texts have been collected from the online Help files of the Google Drive application. Many aspects of the translation process should be addressed and presented, highlighting the main CAT (Computer Aided Translation) tools, being used in the current modern IT translation, such as SDL Trados, MemoQ, Memsource, etc. This paper attempts to investigate and analyze both the principles and problems of translating IT terminology from English into Arabic. It attempts to highlight the debate concerning translingual borrowing as well as the accurate rendering of Arabic terminology in the field of computers and telecommunications. The paper widens its scope to include all grammatical categories and cultural contexts. It also provides a systematic approach through which the translator will be able to create specific terms during the translation cycle.

\section{Discussion}

Linguists and translators utilize and tend to Arabization as a means of translation, especially in the field of technical terms and specialized scientific and technical terms, which is unable to find a counterpart. In case that the translator is unable to develop a purely Arabic word, he/she shall use Arabization, taking into account its rules as much as possible. This part will also address the intricacies involved in rendering a technical Arabic term in the IT (Information Technology) subject matter. The plan of this paper draws insight from current technical applications such as Microsoft and Viber, etc. The paper includes 
authentic examples of translated systems. An example of these translated common terms is "Servers". There are many translations of this very common name in the field of IT, as: سيرفرات - خوادم - ملقمات. As for the previous 3 examples of translation, the linguist followed 3 different approaches and standards. Also, another example is "Sensor" which is translated into:

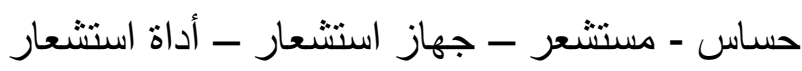

The rapid developments in new information and communication technologies are accompanied by an important boom in the quality and diversity of generated and handled information, in particular, which is available on the internet. This last, being intended for a wide and varied audience, is transcribed in different languages which have brought out the need to internationalize content to allow the widest possible sharing of data between users handling different languages. Thus, transliteration techniques find all their interest to make this prospect of sharing possible.

The translation generation system is based on a training dictionary and does not take into account the punctuation not listed or unknown in the dictionary. This is the case with the system of transliteration of English names into Arabic proposed by (Abdduljaleel Larkey, 2003). This system is based on calculating the most probable form, which is supposed to be the correct form. Now, this hypothesis is not verified for all Arab countries or all dialects.

In order to refer to all the possible cases of the transliteration of an Arabic name in Latin script, related to transliteration based on the phonetic system of literary Arabic as well as on the majority of dialect 
families, taking into account the many regional and local variations. The Localization industry promotes cultural adaptation. A localized product is a reflection of its target culture as if it was originated in such market and, on the other hand, due to the economic pressures, the industry seeks to develop a product that can adapt to the different cultural and linguistic conventions of all markets in which it will be mastered without having to redesign it (LISA, 1995, p. 3). According to Mona Baker, the translated language has its own characteristics and is a comparable variety to the language of original texts. Cultural particularities are at the heart of translation, and the issue of localization is all about the differences between cultures to translate from English to Arabic, it is important to take into account the differences in the codes of verbal and social interactions of different cultures.

For Holmes, work in this cultural area is not very detailed; the cultural perimeter is often confused with the linguistic perimeter and certain theoretical elements. T produce an adequate target text, the translator must have a number of maximum information on the situation for which the translation is required (including on the recipients). Ideally, this situation is defined by the sponsor in a specification Based on the specifications and the translator's translation of the source text, the translation will oscillate between two extremes: from literal translation to adaptation to the standards and conventions of the target culture. Culture is of paramount importance in this theory. 


\section{Samples of Problem Cases}

\section{Problem Case 1}

\section{Source Text}

Viber was initially released in last October 20, 2000.

\section{Explanation of the problem}

Some of the changes required for localizing web pages and applications are not a matter of translation; changes to character encodings, date and time formats, sorting rules, etc. are very important for the translator to take into account. When a software is designed to be launched in a different international market, technical translators step in to adapt it culturally and linguistically to make sure that its users feel that it has been originally written and designed in their own language. That goal is not easy to achieve if the product has not been properly internationalized.

Viber is a brand name. The language of a product or service is of great importance in creating your brand and in your web presence. Also, a product's website can be considered as a means of marketing that accompanies that product, since the web presence can help to build the corporate image. This means that the language of a brand must be something that is taken care of in detail, both in its design in the original language as well as in its translation into Arabic. Brand names have a great impact on the success of a product and they even determine the purchasing options of buyers and it is critical to the success of a new product.

The translator, to ensure that the user of the localized content 
can follow the instructions correctly, will have to check how the items marked in bold are translated in the Operating System of Arabic Windows that suits the Arabic Saudi culture. Therefore, the translator will find himself in the dilemma of maintaining a more or less generic translation, or translate this segment according to the latest version of the Operating System. The main issue in this example concentrates on how the user will deal with translating the date: October 20, 2017. Firstly, the English formal date format starts with the month followed by the day from left to right. Secondly, the Saudi culture and law approves the Hijri calendar mainly in their formal operations in addition to the Gregorian calendar. As per Skopos theory, that considers and respects the local culture during the process of localization, the date format and structure should be adapted and modified to meet the Egyptian and Saudi cultures and regulations, as selected examples to apply to. The other issue that will face the translator is to check the formal translation of the brand name which is Viber.

\section{Suggested translation into Arabic}

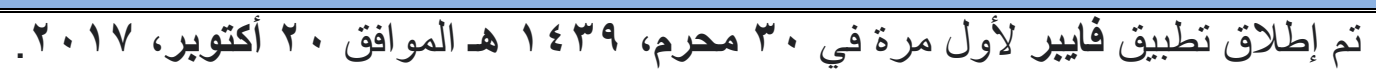




\section{Problem Case 2}

\section{Source Text}

Messages sent before January 1, 2020 (using date format YYYY/DD/MM)

\section{Explanation of the problem}

In this case, the problem lies in the location of two dates that appear in the segment (mainly the second one marked in bold). On the one hand, a developed date appears "January $1, r \cdot r \cdot$ " and, on the other, a date format of a search operator "YYYY/MM/DD". Habitually, when international date variables are translated, they should be adapted to the conventions of the target country, a problem of functional contextual adaptation that the expert translator often automates with ease. However, the second case that affects the date operator format could be more conflictive for the translator when considering what its use will be (if he does not consider it, he will possibly incur an error). In the Arabic culture, as in Egypt, this western format may not be approved and accepted. Moreover, it is not common between the public. The technical translator should be highly aware of the local culture and environment of the area where the product will be used and consumed.

In this case, the problem lies in the localization of two dates that appear in the segment (mainly the second one marked in bold). On the one hand, a developed date appears "January 1 , $r \cdot r . "$ and, on the other, a date format of a search operator 
"yyyy/mm/dd". Habitually, when international date variables are translated, they should be adapted to the conventions of the target country, a problem of functional adaptation that the expert translator often automates with ease. However, the second case that affects the date operator format (yyyy/mm/dd) could be more conflictive for the translator when considering what its use will be (if he does not consider it, he will possibly incur an error).

\section{Suggested translation into Arabic}

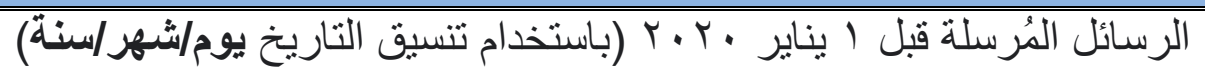

\section{Problem Case 3}

\section{Source Text}

Scroll down in the box that pops up on the right-hand side of the screen to see activity organized with the most recent changes at the top.

\section{Explanation of the problem}

The writing direction is not the same in all languages, there are several options: the right to left (RTL) as in Arabic languages, left to right (LTR) as in English. In this case, the problem lies in the translation of the box, which apparently does not involve many difficulties. Possibly, a professional translator will have doubts when translating boxes, as he will know that it can refer to a dialog box, window, box, and so on. (Translatability). Normally, there is a difference between the English and Arabic 
web pages regarding the directionality. The English language is LTR language where is the Arabic language is RTL language. Accordingly, the direction should be flipped and turned over. Apparently, the right corner should be left and the left corner should be right.

In this case, the problem lies in the translation of the box, which apparently does not involve many difficulties. Possibly, a professional translator will have doubts when translating boxes, as they will know that it can refer to a dialog box, window, box, and so on (Translatability). Normally, the box is usually translated as a box, and a pop-up refers to a pop-up element that appears when performing some action in the interface, such as clicking on an icon or a button. Therefore, if the translator cannot see the visual element itself, their concept will be translated confusing for the user, even erroneous, and the user may not be able to perform the desired action.

\section{Suggested translation into Arabic}

قم بالتمرير لأسفل في المربع المنبثق على الجاتب الأيسر من الثاثة لمشاهدة النشاط

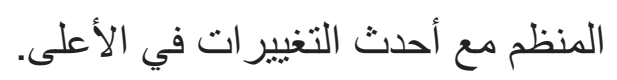




\section{Problem Case 4}

\section{Source Text}

\section{Explanation of the problem}

Like other types of materials, certain regional or local attributes must be taken into account: weight and measurements, date format, paper size, currencies, legal requirements, local contact information, or other cultural differences. Certain icons may not be suitable in a given target culture, such as images with a high cultural load such as a flag. In general, symbol that represents a way of life deserves special attention, such as religious visual elements or symbology of nature. The localization of images is related to two main factors: global appropriateness (international adequacy) and localization (ability to be localized). The first factor has to be cared about with elements of high cultural load such as what have been explained before: flags, direction icons, letters, human body parts, etc. The second refers to the technical image editing process and its costs. Due to the wide variety of elements that may be present on a website, to translate a website, it is necessary to adapt a series of typical parameters to the target market, regarding localization (currencies, dates, measurement systems, etc.). The common elements of web content that require special attention, from the perspective of this research, are the colors, multimedia content 
(images, audio, and video) and hyperlinks. Many of the leading technology companies, such as Facebook, Twitter or Dropbox use very neutral designs and most of them use blue as the predominant color of the website, because it relates to intelligence, trust, efficiency and communication. Religious symbols, parts of the body or hand gestures, national symbols or maps with controversial borders must be taken into account. Even visual codes that are designed to be universal, such as emoji, have different use and interpretation in each country and culture. In particular, it is necessary to be cautious with the use of flags to indicate the multilingual nature of the site.

In this example, where the source currency used in a specific website is the dollar sign, the translator should be aware of the target country that will use this localized website. So, changing the Dollar sign into a local currency is of a vital requirement. In the above example, the translator takes into consideration the adaptation of the skopos of the ST where the rules of the sender limit his choices. In other situations, such rules could be regarded as unethical or immoral where the loyalty of the translator toward the norms and ethics of the target culture should prevail. Terms that may have bawdy meanings or anti-cultural norms should be settled with the client. There is a possibility that the translator might refuse to produce the translation which is one of the challenges in the field of localization.

\section{Suggested translation into Arabic}




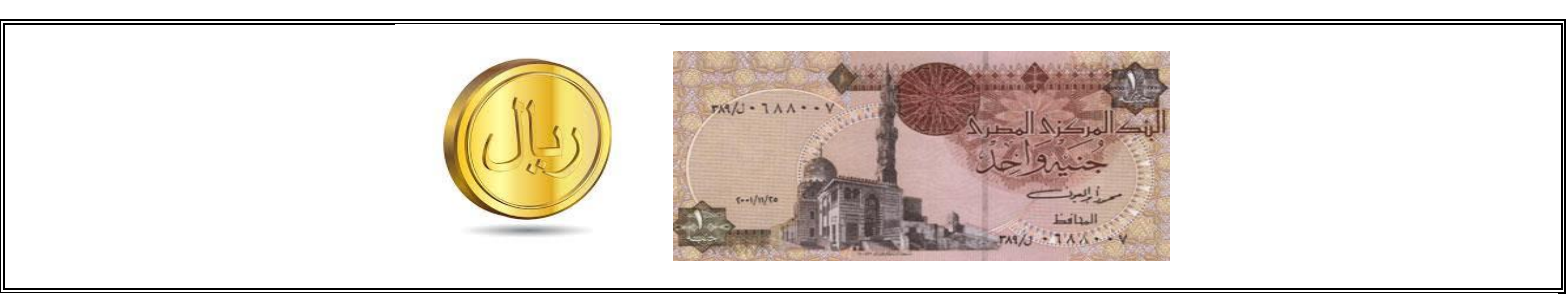

\section{ANALYSIS AND DISCUSSION}

As translation is indispensable in everyday life, translating terminology poses a huge linguistic challenge. Actually, there is a serious shortage of terminology in the Arabic language where transliteration and borrowing could be the only solution. Furthermore, sometimes the same terminology differs according to various platforms and applications (Mac, OS) that may generate more challenges. Yet, with the huge flux of technical information in different domains and with the worldwide freelance translations, a new progressive and sophisticated industry is waiting for more than a modification of the source text. This part focuses on the identification and categorization of problems of localization of online help for web applications. While online help is one of the most voluminous components of project software localization and, therefore, involves a large investment by the manufacturer (Koch, 2003, p. 17), it is sometimes considered a product of lower visibility or priority concerning another type of content (Esselink, 2000 , p. 168). So, for example, the user interface of an application, which is decisive for the success of a computer product because it is responsible for its operation and usability, usually receives maximum attention in the face of documentation or online help, which is sometimes processed secondarily. The general objective of this work is to analyze and provide a categorization of the problems localizing online help for 
web applications. This part explores the types of challenges that a translator faces in the localization of online help.

The main objective of this part is to identify and analyze the types of problems that face the translator in localizing the online help. The translator will have to face other types of obstacles related to the digital nature of the product, and the context and expectations of localization. It is necessary to explore the concept of the translation problem in-depth, the effects of this research, and differentiate the concept of the problem from the notion of translation difficulty, establishes its relationship with translation errors, as well as exposes briefly other related cognitive aspects, such as the interrelation of problems with translation competence, problem-solving skills, and strategies translation.

A product performance problem is a localization obstacle produced by segments that are contextualized concerning functions or characteristics of the locatable product. The main objective of the online help content is that the user can develop a specific action (for example, share a folder with another user or modify bandwidth settings, in the case of corpus products selected), so the content must be clear, explanatory, and precise. That is why the fragments in which the functions of the product are described must be translated correctly and accurately, otherwise, the user may not be able to follow instructions or may not understand how to perform a concrete action. If the translator is not sufficiently familiar with the context of the IT product itself, you will likely have problems translating certain fragments related to the operation of the product. For the professional practice of translation, 
especially specialized translation, several authors emphasize the need for the translator to know the subject of the texts that he translates or that is even specialized or maybe documented around a specific subject area (medicine, marketing, technology, etc.) (Esselink, 2000, pp. 9, 451).

In the case of software localization and online help, this thematic sub-competence implies that the translator should be familiar with the IT product in question (or extensively documented) to produce a quality localization and to translate the product functions and the user interfaces correctly. Van Den Broeck describes what he calls a 'basic' translator competence as the ability to deal with texts as a translator, that is to transfer the texts in the most appropriate way from one language to another, from one culture to another and from one system of textual conventions to another. (1980, p. 86) Alternatively, Pym defines translation competence as the union of three skills; to generate, to select, and to propose: "The ability to generate a target text series of more than one viable term and the ability to select only one target text from this series, quickly and with justified confidence, and to propose this target text as a replacement of source text for a specified purpose and reader" (1992, p. 281)

Both definitions refer to the competence of the translator as an 'ability' which demands skill. In case the translator has access to the product with which he is going to work, either because your client has provided it, either because it is a product accessible in a public, it is advisable to spend time familiarizing yourself with the product, its structure, and its main functions. This familiarization makes it possible to 
produce higher quality work and the time invested pays off especially if the relationship with the client is durable.

\section{Results and Recommendations}

This paper looked at the impact of technical tools on productivity and quality. The main recommendation is to adapt the content of university training to this person-machine relationship. This relationship maintained with the translation assistance tools by business experts has, however, not yet an object of paper. This object of paper is difficult to understand for the university researcher because he must work in the field. Below is a detailed overview of the findings and results of this paper:

1- Analyzing localization as a discipline of paper and as a professional activity. The intersection between translation and new technologies has brought very deep changes not only in the translation process but also in the notion of text and even in the way in which the figure of the translator is conceived. Although of the increased productivity and efficiency of translators, sophistication of translation systems is a factor that has clearly positive implications.

2- The localization of the online help shares elements with both the LPI (Localization of product information) and the website localization, mainly because the difference between these two products is increasingly diffuse. These synergies are mainly proposed due to the industry trend of developing web applications, which are generated in a dynamic way using a web browser. The 
help of the various products has also followed this trend, hand in hand with web-based help systems (online help).

3- As explained, in the localization of a product, the context of the target culture, the purpose of the product itself and the customer's expectations (aspects clearly related to the notion of skopos) play a fundamental role in the decisions made by the translator. This aspect is a key element in the notion of the problem that is being worked on in this research.

4- The problem of translation is a notion that has not been the subject of many empirical investigations possibly due to the difficulty and cost of conducting experimental studies focused on cognitive aspects. In the present work, it has been chosen to empirically address the analysis of the localization problems through a qualitative study, with special attention to a notion of research quality focused on promoting the parameters of internal validity, reliability, and external validity (Merriam, 1995, 1998), in an eagerness to achieve significant results that may be applied in future broader investigations.

5- From the perspective of this paper, the notion of the problem is linked to the context of the translation or localization project, to the origin and target cultures, to the purpose of the project and the translator himself.

6- After exploring the notion of problem in Translation Studies, it is concluded that there are four variables that describe its nature in one way or another: the experience of the translator, the objectivity or subjectivity of the notion of problem, automation of the solution and the transfer phase from source to target text. 
7- The content of the online help is subordinate to various factors that have a direct influence on the localization process. The purpose of the help center and the context of the product influence the decisions of the translator at a general level, but other aspects, such as its hypertext nature, visual elements and content technological, determine and, to some extent, limit the translation process.

8- The main and typical communication functions of online help are: the function referential, because a topic is exposed and explained to the receiving user, and the function appellative, because this type of content provides instructions on what a user should do if he wants to perform a certain action and, in addition, urges him to follow certain recommendations. 


\section{Conclusion}

Since 1976, translation has been treated as a segment or a subfield of applied linguistics and literary studies. In this respect, the cultural aspect of translation has been neglected, while equivalence and faithfulness have remained the main criterion. But Linguistics alone will not help us. Translation is not merely and not even primarily a linguistic process. Alongside the rise of translation studies, a turn has been made toward cultural studies and what can be called cultural translation. To govern and regulate the translator's behavior during the translation process, he should be norm-governed. In other words, moving between two different languages and cultures, as in the case of Arabic and English, the translator should bear in mind the target reader and the acceptability of the final product.

Translating IT terminology from English into Arabic language entails numerous problems due to the differences between Arabic and English languages. In the light of Skopos theory, this paper has attempted to scrutinize the prevalence of translated English IT terminology in the Arab region as a method to convey information. It has also endeavored to explore the translators' awareness of translingual borrowing and Arabization (التَنْرِيبْ).

Translating technical terminology is an object-centered translation that uses Arabization (transliteration) or Arabic expanding techniques to translate materials dealing with different fields of technology. Understanding and reformulating a technical IT text requires linguistic and extra-linguistic knowledge. The translator must acquire a knowledge base to be able to translate. The translation consists of understanding 
the original English text and reformulating it into the target Arabic language. However, the translator rarely has the extra knowledge that will allow him to translate a technical IT text. Technical IT translators should dedicate some time to acquiring specialized knowledge of the technical IT industry. The translator does not have as much knowledge as a specialist does because he has generally not taken full-fledged training in a technical IT area. The translator can build his sources by archiving the translation of terms that have been found on the occasion of previous documentary research. He can do his archiving work while translating or preparing future translations and can add a definition, context, or other information. This method is an investment because the translator can find information that will be used for future translations. Consequently, a memory of translation is a file organized in a concordance table or equivalences between segments of two texts. The software submits to the translator a translation segment that was saved previously in memory; the translator is free to accept or reject this proposal.

Applying the rules of Skopos theory helps to investigate the procedures of IT translation as well as identify the problems faced by the translators. Both purpose and aim of the target text should not be applied blindly. In addition, the translator can move between translating freely or faithfully according to different situations. Yet, the most important part of this process is transferring the function effectively by whatever method.

Indeed, in a world that is experiencing a constant increase in interest in computers, it seems relevant to us to stress that, in the field 
of computer-assisted translation, every translator should be aware of this fact and learn to use translation assistance tools which are very useful when he knows how to use them.

Throughout our work, we have observed that translation remains an essentially human activity. However, attempts have been made to automate and computerize it (machine translation), or to use computers as a medium for human translation. (Translation assisted by computer). Translation tends to become more and more machine translation. The available tools to translators will become more efficient and we can use them to produce translations that come closer and closer to accuracy. In other words, the translator will only have to adapt to these new technologies in order to remain competitive in the long term.

The content should take into account the ways of thinking, value systems, prejudices, tastes, expectations, and the "culture" of the target audience. A good translation respects all the conventions applicable to any communication and, in particular, all the local constraints and regulations. We, therefore, hope that this work will be useful to all technical IT translators and to all those who are directly or indirectly interested in this field. 


\section{REFERENCES}

Abdulbaqi, K. K. (1981). Problems of linguistic semantics with reference to translating English poetry into Arabic (Order No. 10662696). Available from ProQuest Dissertations \& Theses Global; ProQuest One Literature. (1941003769). Retrieved from https://www.proquest.com/dissertations-theses/problemslinguistic-semantics-with-reference/docview/1941003769/se2 ? accountid $=178282$

Al-Awthan, A. (2019). Arabicization and terminology with reference to social media terms (Order No. 13813999). Available from ProQuest Dissertations \& Theses Global. (2234293620). Retrieved from https://search.proquest.com/dissertationstheses/arabicization-terminology-with-referencesocial/docview/2234293620/se-2?accountid=178282

Alderbashi, B., \& Haroon, H. (2020). Translating Jinns in Naguib Mahfouz's layali alf layla into English. 3L, Language, Linguistics, Literature, 26(4) doi:http://dx.doi.org/10.17576/3L-2020-2604-11

Allen, J. (2000). Post-Editing or No Post-Editing? International Journal for Language and Documentation, vol. 8, pp. 41-42. Science Publishing Group. New York. ALPAC Report. (1966). Language and Machines. Computer in Translation and Linguistics. Division of Behavioral Sciences. National Academy of Sciences.

. (2001). Post editing: an integrated part of a translation software program. Language Magazine: Improving Literacy \& 
Communication, flight. 13 (2), April, pp. 26-29. Language Magazine. Malibu, California.

Archer, V. (2009). Multilevel linguistic graphs for extracting knowledge: the example of collocations. Doctoral thesis. University Joseph-Fourier. Grenoble.

Baker, M. (1987). Review of methods used for coining new terms in Arabic. META, 32(2), 186-188.

. (ed.) (1998) Routledge Encyclopedia of Translation Studies. London and New York: Routledge.

. (1993). Corpus Linguistics and Translation Studies: Implications and Applications. MG-B. Baker (Ed.), Text and Technology, pp. 233-250. John Benjamins Publishing Co. Amsterdam.

Ballard, M. (2006). What are translation studies? Artois University Press. Arras.

Berman, A. (1989). The translation and its speeches. Meta Journal of translators / Meta Translators Journal, vol. 34 (no 4), pp. 672679. The Presses the University of Montreal.

Boushaba, S. (1988). An analytical study of some problems of literary translation: A study of two arabic translations of $K$. gibran's0RW1S34RfeSDcfkexd09rT2 the 
prophet1RW1S34RfeSDcfkexd09rT2 (Order No. 27796784).

Available from ProQuest Dissertations \& Theses Global;

ProQuest One Literature. (2342096843). Retrieved from

https://www.proquest.com/dissertations-theses/analytical-study-

some-problems-literary/docview/2342096843/se-

2 ? accountid $=178282$

Byrne, Jody (2006) Technical translation. Usability strategies for translating technical documentation, Dordrecht: Springer.

De Jesus Martins, D., \& De Medeiros Caseli, H. (2015). Automatic machine translation error identification. Machine Translation, 29(1), 1-24.

Retrieved March 31, 2021, from

http://www.jstor.org/stable/44113783

EL-KHAFAIFI, H. (1985). The Role Of The Cairo Academy In Coining Arabic Scientific Terminology: An Historical And Linguistic Evaluation (Order No. 8524161). Available from ProQuest Dissertations \& Theses Global; ProQuest One Literature. (303426882). Retrieved from

https://www.proquest.com/dissertations-theses/role-cairoacademy-coining-arabic-scientific/docview/303426882/se2 ?accountid=178282

Esselink, Bert. 2000. A Practical Guide to Localization. Amsterdam and Philadelphia: John Benjamins.

GAGNON, C. (2006). Ideologies in the History of Translation: A Case Study of Canadian Political Speeches. In G. L. BASTIN \& P. F. BANDIA (Eds.), Charting the Future of Translation History (pp. 
201-224). University of Ottawa Press.

https://doi.org/10.2307/j.ctt1ckpfkh.15

Garcia, I. (2007). Power Shifts in Web-Based Translation Memory. Machine Translation, 21(1), 55-68. Retrieved March 31, 2021, from http://www.jstor.org/stable/30219110

Ghazala, H. (1995). Translation as problems and solutions: A coursebook for university students and trainee translators. Valetta, Malta: Elga.

Greenstein, E. L. (2020). Theories of Modern Bible Translation. In Essays on Biblical Method and Translation (pp. 85-118). Brown Judaic Studies. https://doi.org/10.2307/j.ctvzpv5k8.11

Hamed, F. Y. (2014). Language tension, terminology variation and terminology policy in the Arabic-speaking north African countries: An alternative approach to terminology practice (Order No. 3672609). Available from ProQuest Dissertations \& Theses Global. (1649168718). Retrieved from https://search.proquest.com/dissertations-theses/languagetension-terminology-variation-policy/docview/1649168718/se2 ? accountid $=178282$

Holmes, J. (1988) Translated papers on literary translation and translation studies, Amsterdam: Rodopi.

LONSDALE, A. B. (1996). Translation (Theory). In Teaching Translation from Spanish to English: Worlds Beyond Words (pp. 23-40). University of Ottawa Press. https://doi.org/10.2307/j.ctt1cn6sgb.10 
Munday, J. (2016). Introducing Translation Studies (Fourth Edition ed.). Oxon: Routledge . (2001) Interspecific competition and coexistence in a guild of coral-dwelling fishes. Ecology 82(8):2177-2189

. 2012. Evaluation in Translation: Critical Points of Translator Decision-Making. London: Routledge.

Newmark, P. (1988a). A Textbook of Translation. Hertfordshire: Prentice Hall.

. (1988b). Approaches to Translation. Hertfordshire: Prentice Hall.

. (1991). About Translation: Multilingual Matters. Clevedon, Philadelphia, Adelaide: Multilingual Matters Ltd.

Nida, Eugene A. 1964. Toward a Science of Translating: With Special Reference to Principles and Procedures Involved in Bible Translating. Leiden: E. J. Brill.

Nida, E. and C. Taber (1969) The theory and practice of translation. Brill: Leiden. 
Nord, C. (1996) Text Type and Translation Method: An Objective Approach to Translation Criticism. The Translator 2 (1): 81 . (2005) Text Analysis in Translation: Theory, Methodology, and Didactic Application of a Model for Translation-Oriented Text Analysis, Amsterdam: Rodopi. Schäler, R. (2002) Reverse Localization. The International Journal of Localization, Vol.6, Issue 1, Localization Research Centre, CSIS Dept., University of Limerick, Limerick Ireland, 39-48.

. (1997) Translating as a Purposeful Activity. Functionalist Approaches Explained. Manchester, UK: St. Jerome Publishing. . (1991b) Skopos, loyalty, and translational conventions. Target 3 (1): 91-109.

O'Brien, S. (2005). Methodologies for Measuring the Correlations between Post-Editing Effort and Machine Translatability. Machine Translation, 19(1), 37-58. Retrieved March 31, 2021, from http://www.jstor.org/stable/20060468

Olohan, M. (2014). Gate-keeping and localizing in scientific translation publishing: The case of Richard Taylor and "Scientific Memoirs". The British Journal for the History of Science, 47(3), 433-450. Retrieved March 29, 2021, from http://www.jstor.org/stable/43820512 
Omar, Ahmad Mokhtar. 2008. Mu'ğam al-Luġä̈ al- 'Arabīä̈ al-Mu așirä̈ [Dictionary of the Contemporary Arabic Language]. Cairo: 'Âlam al-Kutub

Osborn D (2001) The knotty problem of using African languages for email and internet. Balancing Act's News Update 69. Accessed 21 June 2009, http://www.balancingact-africa. com/news/back/balancing-act_69.html

Osborn D, Anderson D \& Kodama (2008) Support for modern African languages and scripts in Unicode/iso 10646: Where are we today? Paper presented at the 32nd Internationalization and Unicode Conference, San Jose, California (10 September)

Uhlmann, A. J. (2015). The Failures of Translation across Incommensurable Knowledge Systems: A Case Study of Arabic Grammar Instruction. In P. G. TONER (Ed.), Strings of Connectedness: Essays in honour of lan Keen (pp. 143-160). ANU Press. http://www.jstor.org/stable/j.ctt183q3jp.14 Vermeer, Hans. 1989/1996. "Skopos and Commission in Translational Action." In The Translation Studies Reader, edited by Lawrence Venuti, 227-238. 2nd ed. London and New York: Routledge. . (1989a) Skopos and Commission in Translational Action, trans. Andrew Chesterman, in Chesterman (ed.) 173-87. . (1978) Ein Rahmen fiireine allgemeine Translationstheorie, Lebende Sprachen 23 (3): 99-102. 
Vinay, J. and J. Darbelnet (1958/1995) Comparative stylistics of French and English: a methodology for translation (translated and edited by J. Sager \& M. J. Hamel), Amsterdam \& Philadelphia: John Benjamins Publishing Company.

Wahba, Magdi. 2008. An-Nafees: The 21st Century English-Arabic Dictionary. 2nd ed. Cairo: Egyptian International Publishing Company - Longman.

Wright, S. E., \&Wright, L. D. (1993). Scientific and technical translation. Amsterdam/Philadelphia: John Benjamins. 


\section{إثكاليات ترجمة مصطلحات تكنولوجيا المعلومات إلي اللغة العربية}

| - مداد/

رامى حمزة محمد شَنيشن

أ.د محمد سعيد نجم

أستاذ اللغويات، كلية الأداب _جامعة طنطا

\section{د. جمال حجازي}

مدرس الأدب الإنجليزي، كلية الأداب _جامعة طنطا

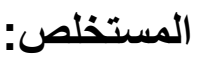

تستكثف هذه الدر اسة التحديات و المشاكل المتتو عة التي يو اجهها المترجمون المتخصصون في مجال تكنولوجيا المعلومات أثناء قيامهم بتعريب وترجمة مشاريع تكنولوجيا المعلومات. بالنظر إلى أن التعريب هو نشاط مفيَّ بمحدودية الوقت و الأسلوب و التكلفة، فإن مترجمي تكنولوجيا المعلومات في حاجة إلى الاستفادة من مجمو عة مهار اتهم الكاملة بهدف التغلب على التحديات المختلفة التي يفرضها النص المصدر و عملية التعريب في حد ذاتها. تقدم الدر اسة الحالية تصنيفًا دقيقاً لمشاكل الترجمة من الإنجليزية إلى العربية، وقد تم الاعتماد في هذه الدراسة على أعمال مترجمة في بعض تطبيقات الويب الفريدة والمهمة مثل أنظمة أور اكل و مايكروسوفت و جوجل و ساب. كما تركز الدراسة الحالية على الأسباب التي تؤدي إلى مثل هذه العقبات و المشاكل وتقدم الحلول المتاحة لتجنب تلك المشاكل. كما تهدف إلى تحليل وتحديد الأساليب العملية والوظيفية في ترجمة مصطلحات تكنولوجيا المعلومات، مع التركيز على العقبات الرئيسية التي تو اجه المترجم المتخصص في مجال تكنولوجيا المعلومات.

تتبع الدر اسة الحالية منهجية ونظرية سكوبوس، والتي تأخذ بعين الاعتبار كل من المعايير الثقافية و البيئية عند نقل النص المترجم من الإنجليزية إلى العربية، وبالتالي يجب أن يكون المترجم التقني ملمًا

للغاية ولديه خبرة واسعة في الثقافة و البيئة التي سيتم فيها طرح وتسويق النص المترجم. كما تهتم الدر اسة بالقيود و المعوقات التي تو اجه أنظمة اللغة العربية و أبعادها وكيفية تفاديها في دمج المصطلحات 
الإنجليزية في النص المترجم للغة العربية. تعتبر نظرية سكوبوس ذات أهمية حيوية في تعريب منتجات الكمبيوتر، و التي تميل إلى أن يكون لها غرض تجاري في المقام الأول. يجب تكييف هذا المحتوى لكي

يتناسب مع الثقافة المستهدفة، وإلا فإنه لن يؤدي نفس التأثثر لاى المستخدم المستهدف. إن معرفة الغرض من المحتوى الذي سيتم تعريبه، من بين أمور أخرى، سيساعد في اختيار نوع اللغة التي سيتم توجيهُا إلى مستخدمي المحتوى المُنَرجمَ.

تركز الدر اسة الحالية على تحديد وتصنيف مشاكل تعريب التعليمات (HELP) الخاصة بتطبيقات الويب. "التعليمات" هي منتج رقمي يقدم المساعدة للمستخدم لتنفيذ مهام معينة في تطبيق معيَّن أو يجيب

على أسئلة حول جو انب معينة من واجهة التطبيق أو كيفية تشغيله أو إلقاء الضوء على بعض من خصائصس. يغطي السؤال الأساسي لهذه الدراسة على نطاق واسع: أنو اع المشاكل التي يو اجهها المترجم أثناء تعريب "تعليمات الإنتزنت". تهدف الدراسة إلى تحليل وتحديد الأساليب العملية و الوظيفية المتبعة في ترجمة المصطلحات التقنية (تكنولوجيا المعلومات)، مع التركيز على المشاكل و العقبات الأساسية التي تو اجه المترجم المتخصص في مجال تكنولوجيا المعلومات. وخلال عملية الترجمة، يتم تحديد مصطلحات تكنولوجيا المعلومات ومناقشتها وترجمتها مع الأخذ في الاعتبار سياق هذه المادة التقنية التي يتم ترجمتها. وخلال العقود القليلة الماضية، تستخدم جميع شركات الترجمة تطبيقات وبر امج Translation ) للترجمة والتي تعتمد بشكل أساسي على بنية وجو هر ذاكرة الترجمة Memory)، و التي يُنّار إليها باسم "TM" في عالم الترجمة التقنية. وتتجلى ضرورة وحيوية هذه وده الأداة في تطبيقات الترجمة التقنية في الحفاظ على اتساق النصوص المترجمة وتماسكها قدر المستطاع، بالإضافة إلى توفير وقت وتكلفة ترجمة الكلمات و الفقرات المكررة في النص الجاري ترجمته. و لا شك أن خبرة المترجم وثقافته العامة تعتبر ضرورة حيوية وملحة، الأمر الذي يساعد على تقديم ترجمة مناسبة ودقيقة.

الكلمات الإفتتاحية: الترجمة العربية ـ تكنولوجيا المعلومات ـ التعريب ـ تعليمات ـ قابلية الترجمة ـ تكافؤ المعنى - نظرية سكوبوس. 